Bangladesh J. Plant Taxon. 20(1): 125-127, 2013 (June)

(C) 2013 Bangladesh Association of Plant Taxonomists

\title{
A NEW COMBINATION IN LITSEA LAM. (LAURACEAE) FROM NORTH EASTERN INDIA
}

\author{
Trina BhUinya ${ }^{1}$ and Paramuit Singh ${ }^{2}$ \\ Central National Herbarium, Botanical Survey of India, Shibpur, Howrah 711103, India.
}

Keywords: New nomenclatural combination; Litsea; Lauraceae.

Tetranthera khasyana Meisn. and Cylicodaphne hookeri Meisn. (excl. var. siamensis Meisn.) are the same species, with differences in the shape of berry and in the peduncles of the fruit and the umbel. Hooker (1886) treated the former plant as Litsea khasyana (Meisn.) Hook. f. and the latter as L. khasyana (Meisn.) Hook. f. var. hookeri. But another plant Litsea khasyana Meisn. already existed. Hence, Long (1984) adopted the name Litsea hookeri (Meisn.) Long for Cylicodaphne hookeri Meisn. Here, Tetranthera khasyana Meisn. is described as a new combination of Litsea hookeri (Meisn.) Long var. khasyana (Meisn.) T. Bhuinya \& P. Singh. The plant is quite common in subtropical forests of Khasi Hills in Meghalaya, and Eastern Himalaya in Sikkim and West Bengal at $400 \mathrm{~m}$ to $900 \mathrm{~m}$.

A key to the varieties of Litsea hookeri (Meisn.) Long is given below:

1. Berry ellipsoid; fruit and umbel peduncle slender

var. hookeri

- $\quad$ Berry depressed globose; fruit and umbel peduncle distinctly stout

var. khasyana

A detailed taxonomic account along with illustration of the plant has been made based on herbarium materials.

Litsea hookeri (Meisn.) Long var. khasyana (Meisn.) T. Bhuinya \& P. Singh comb. nov. Tetranthera khasyana Meisn. in DC., Prodr. 15(1): 185 (1864); Litsea khasyana (Meisn.) Hook. f., Fl. Brit. India 5: 164 (1886). Nom. Illeg. (non Meisn. 1864); Kanjilal et al., Fl. Assam 4: 85 (1940).

(Fig. 1).

Type: India: Meghalaya, Khasi Hills, J. D. Hooker \& T. Thomson s.n. (Holotype - G-DC microfiche!)

Perennial, evergreen, dioecious tree, 8-12 m tall. Branchlets cylindric, yellowish brown, puberulous when young, glabrous at maturity. Leaves 9.5-22.5 $\times$ 4.5-8.7 cm, alternate, ellipticoblong, cuneate at base, entire, shortly acuminate at apex, coriaceous, dark green, glabrous, primary and secondary veins depressed above; beneath pale green, glabrous, except on veins, primary and secondary veins prominent, secondary veins 10-15 pairs, weak brochidodromous, tertiary veins alternate, percurrent, sinuous; petiole 1.5-2.0 cm long, cylindric, puberulous. Umbellules 10-12 × 8-15 mm, axillary, solitary or in clusters of 3-5, 6-flowered, pedunculate, bracteate; peduncles 4-6 mm long, stout, swollen, yellowish brown, densely puberulous; bracts 6, outer two 4-6 × 6-7 mm, concave, coriaceous, yellowish green, densely puberulous outside, glabrous inside, inner four 4-6 × 5-6 mm, orbicular, membranous, gland-dotted, green, puberulous outside, glabrous inside. Flowers 3.5-4.0 × 3.0-3.5 mm, white; pedicels 1-2 mm long, stout, green,

${ }^{1}$ Corresponding author. Email: trina.bhuinya@gmail.com

${ }^{2}$ Botanical Survey of India, C.G.O. Complex, Salt Lake City, Kolkata 700064, India. 


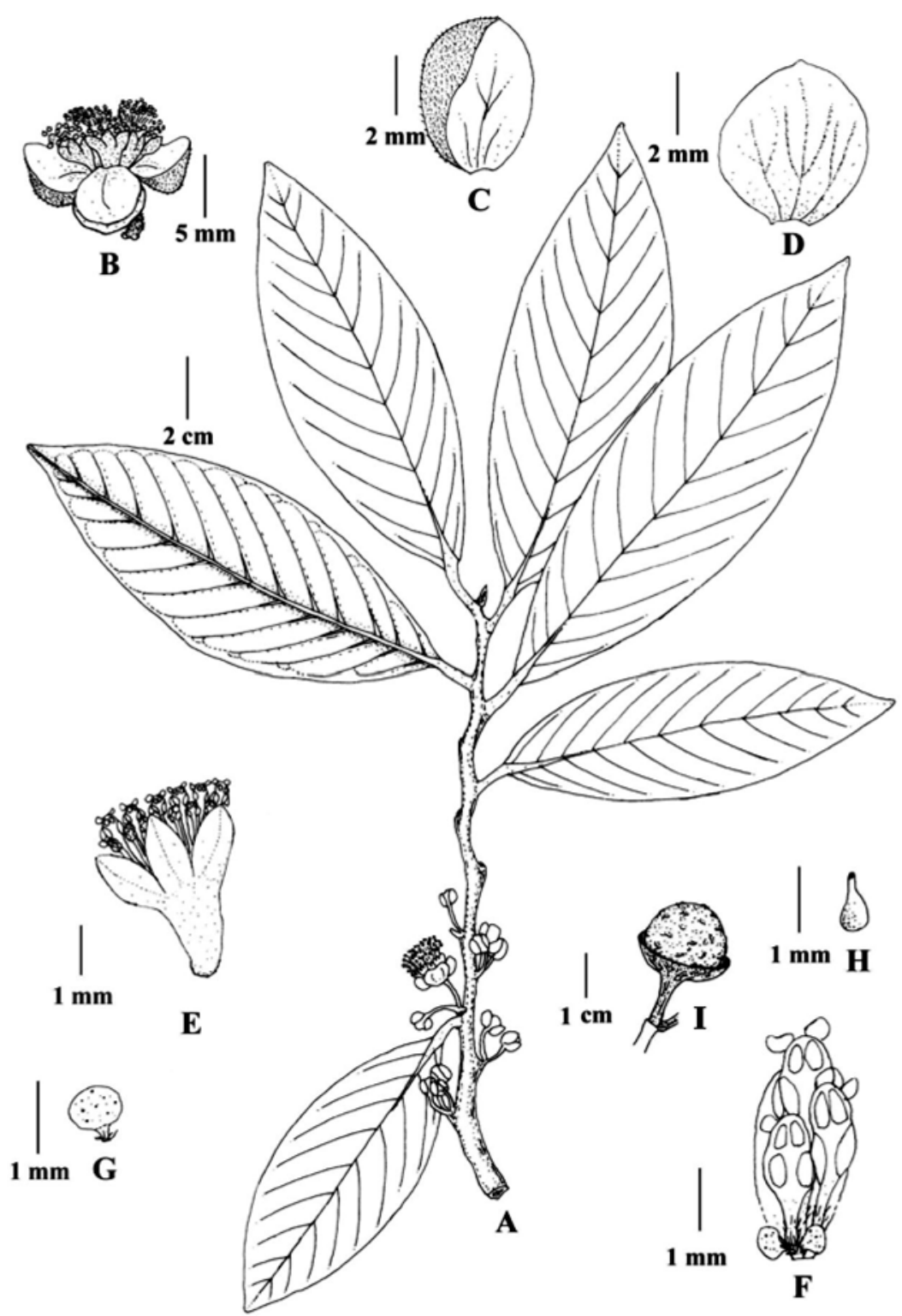

Fig. 1. Litsea hookeri (Meisn.) Long var. khasyana (Meisn.) T. Bhuinya \& P. Singh comb. nov. A. Habit; B. Inflorescence; C. Outer bract; D. Inner bract; E. Flower; F. Tepal with stamens; G. Gland; H. Pistillode; I. Fruit. (A-G: G. King, acc. no. 386868; I: G. King, acc. no. 386888).

puberulous; perianth lobes 6, 2.5-3.0 × 1.5-2.0 mm, elliptic, gland-dotted, puberulous outside, glabrous inside except at base, perianth tube 1.0-1.5 mm long, funnel shaped, green, hairy inside, densely puberulous outside. Male flowers: stamens 12, in 4 rows, outer 2 rows 2.5-3.0 mm long, exserted, inner 2 rows 1.5-2.5 mm long, glandular; filaments slender, hairy at base; anthers 1.0-1.5 $\mathrm{mm}$ long, 4 celled, upper 2 cells introrse, lower 2 cells partly latrorse; glands $0.8-1.0 \mathrm{~mm}$ long, 2 
each at base of inner rows of stamens, bean shaped, subsessile, hairy at base; pistillode $0.5 \mathrm{~mm}$ long. Female flowers: staminodes 12, in 4 rows, outer 2 rows 3.5-4.0 mm long, exserted, inner 2 rows 2.5-3.0 mm long, glandular, hairy at base; pistil 3-4 mm long; style 1.8-2.5 mm long, glabrous; stigma spreading, ovary 0.8-1.2 mm long, globose, glabrous. Berries 15-18 × 8-11 mm, depressed globose, green when young, purple at maturity, glabrous, seated on persistant perianth tube, perianth tube saucer shaped, 12-16 mm in diameter, entire, dark brown, glabrous; pedicle 5-8 $\mathrm{mm}$ long, stout, dark brown, puberulous; fruit peduncle 6-9 $\mathrm{mm}$ long, stout, swollen, yellowish brown, puberulous.

Flowering period: March to June. Fruiting period: May to September.

Conservation status: Litsea hookeri (Meisn.) Hook. f. was reported from Bhutan, Nepal and India (Arunachal Pradesh, Meghalaya, Sikkim and West Bengal) but till date L. hookeri var. khasyana was reported from India (Meghalaya, Sikkim and West Bengal) only. Hence the taxon is an addition to the recently published list of endemic species of Litsea Lam. in India (Bhuinya et al., 2010). At present the plant is not under the threat of depletion, but the areas being popular tourist spots, are under extreme biotic pressure which may pose a threat to the existence of the species. Hence plant explorers from these areas including Bhutan, Nepal and Arunachal Pradesh (India) are urged to collect the plant and confirm its identity in order to determine its present status.

Specimens examined: India. Meghalaya, Khasi Hills, Kurz 386975, 386878, 386896 (CAL); Sikkim, G. King 215 (CAL); Sikkim, 3500 ft, 19.6.1876, G. King 386868 (CAL); West Bengal, Darjeeling district, Mungpoo, 11.12.1877, G. King 386885, 386886, 386889 (CAL); Darjeeling district, Banks of Teesta, 26.2.1876, G. King 386867, 386888 (CAL); Darjeeling district, Teesta, 22.2.1867, Anderson 386891 (CAL).

\section{Acknowledgements}

The authors are thankful to the Indian Botanical Liaison Officers, Royal Botanic Gardens, Kew, UK and the Joint Directors, Central National Herbarium, Shibpur, Howrah for their help. They would also like to thank the Director, Botanical Survey of India for awarding the fellowship under the 'Flora of India Project'.

\section{References}

Bhuinya, T., Singh, P. and Mukherjee, S.K. 2010. An account of the species of Litsea Lam. (Lauraceae) endemic to India. Bangladesh J. Plant Taxon. 17(2): 183-191

Hooker, J.D. 1886. Lauraceae. Flora of British India. Vol. 5. London, p. 157.

Long, D.G. 1984. Notes related to the Flora of Bhutan: VIII. Notes R. B. Gard. Edinburgh 41(3): 510-511. 